\title{
Role of the United Nation Security Council in Resolving International Disputes
}

\author{
${ }^{\text {A}}$ Faculty of Law, National University of Malaysia \\ ${ }^{\mathbf{B}}$ Faculty of Law, National University of Malaysia \\ CDepartment of Business Administration, Koya Technical Institute, Erbil \\ Polytechnic University, Iraq and Universiti Tun Hussein Onn Malaysia, Malaysia \\ ${ }^{D}$ Faculty of law and political sciences, Nawroz university
}

Pasar Abdulkareem Fendi , Salawati Mat Basir ${ }^{b}$ and Bestoon Othmanc, Muaid Muhamad Abdulqader

Article History: Received: 11 January 2021; Accepted: 27 February 2021; Published online: 5 April 2021

\begin{abstract}
The United Nation (UN) was established after World War II on 24 October 1945 to preserve international peace and security, developing friendly relations between nations fostering respect for human rights. All UN Member country have decided, furthermore adopting their decisions that United Nations Security Council (UNSC) should implement its duties independently. And promoting mutual cooperation in the peaceful resolution of international problems. The UN operates with the help of the six principal organs. One of them is a fifteen-member UNSC. Only recommendations can be made by the other UN bodies. For states. Nevertheless, the UN Member States have mutually agreed in the case of UNSC that UNSC must implement its duties independently. This is the only UN body that can pass a legally binding resolution on the member states. The United Nations have played a significant role in resolving disputes among the different countries over many decades, with the aid of the UNSC (the main body that is in charge of sustaining peace and security). An important implication of this study is that responsibility practices are normative and constrictive in their effect as they organize both our practices and our interpretation on the world in distinctive and contingent ways, which is of central relevance to political decisions about the design of social institutions generally.
\end{abstract}

Keywords: United Nation; Security Council; Solving International problems; Disputes

\section{Introduction}

After the Second World War, on 24 October 1945, the United Nation (UN) was developing to maintain international peace and security (Arnold, 2001) and developing friendly relations between nations promoting respect for human rights (Art. 24, 1945). Furthermore adopting its decisions, all UN Member States have insisted on the sovereignty of UNSC. And promoting cooperation in the peaceful resolution of international problems. The UN operates with the help of the six principal organs. One of them is a fifteen-member United Nations Security Council (UNSC). Nevertheless, the UN Member States have mutually agreed in the case of UNSC must implement its duties independently. This is the only UN body that can deliver a legally binding resolution on the member states. There is a service laid down to be implemented by the UNSC to preserve international peace and security. For instance, in the event the dispute, the council has to first convince the parties concerned to settle their conflicts in a friendly or peaceful manner. In this case, the council may interfere by nominating a special representative or may ask the UN Security Council to nominate a special representative to investigate the matter (Christian, 2000). Therefore, it is the duty of the council to lay down those rules or principles for the sake to resolve a disputes peacefully. The UNSC takes the initiative to see that the maintenance of international peace and security in the world is without risk or danger. It also means that violence does not happen (Adam, 2000). It calls on the contested nations to settle in a peaceful manner their misunderstandings or disputes. It also proposes settlement methods and it Uses force in some situations to restore peace and security in the world (Lau, 2005). Security can be preserved everywhere in this way. The council may also choose to take robust action including: not allowing diplomatic relations; termination of diplomatic relations; blockade; joint military action. Economic and punitive fines, travel bans, etc. furthermore, the UNSC, which is furthermore harmonizing nation policy, may also recommend the UN General Assembly, the appointment of the Secretary-General and the incorporation of new members in the UN. For addition, the UNSC also elects judges from the International Court of Justice.

Despite the clear above provisions that provide Despite making arrangements to ensure international peace and security through UNSC, it has faced a great deal of criticism from politicians for many reasons, some of these reasons are related to its relationship with the General Assembly, its undemocratic framework (Sydney, 1998) its working methods and, of course, its small size. Most of the criticism was due to the "power of veto" used in an egoistic way by the ve permanent members of the council, namely the United States, Russia, the United Kingdom, and China, to suppress any non-procedural issue by casting their negative vote given their level of international support. Due to of the above explanation, the author chose this research topic to find ways to revamp the UNSC's role in preserving and sustaining international peace and security. 


\section{Literature review}

\subsection{Concept and meaning of the idiom 'International Dispute'}

Studying the definition the dispute is significant for two significant reasons as explained below; the analysis of global armed dispute is due to foreign and inter-state conflicts. They should note that no disagreement must result in an armed war; on the other hand it would lead to pain, suffering, horror, death, etc. It is going to leave many homeless and unemployed. This will affect the environment. Fighting is bringing total destruction. Therefore, for the sake to avoid the negative and hazardous consequences the dispute, we must use all possible methods to resolve disputes under international law for the sake to resolve disputes.

Black's Law Dictionary explained 'dispute' as a dispute that gives rise to a lawsuit; in the case of Mavrommatis Palestine Concessions, the Permanent Court of International Justice explain a dispute as a dispute on the point of law or fact, the conflict of views or interests between two persons Arts. 2 (1945). According to the International Court of Justice, a dispute is characterized as a situation in which the two sides clearly expressed opposing views on or relating to the performance or non-performance of specific Shabtai treaty obligations (2006).

While international disputes have become a common phenomenon in the 21 st century, and while everyone knows the meaning of the conflict, few know the meaning of the idiom ' international dispute' in actual practice. The current phrase meanings did little to explain the idiom.

In the case of Texaco overseas petroleum company and the case of California Asiatic Oil company, the Tribunal described dispute as a ' current difference of interests and opposition of legal opinions ' (B. A. Garner, 1999). It is also clear that if there is dispute in any part of the world between government, organization and any private individual, there will be international dispute. 'International dispute' or 'interstate dispute' is not limited to disagreement or complaint alone. It is a sort of particular conflict between two or more states that reaches a point of interpretation and consistency where it is possible to use specific existing means the dispute resolution under international law, such as negotiation, mediation, conciliation arbitration and adjudication, to resolve a dispute.

The idiom has also been described by the International Court of Justice as International law on dispute settlement comes into play when a dispute rises to a degree a dispute (Peace Interpretation, 1950).The most important aspect of this legislation is that all conflicts must be resolved in a peaceful manner so that there is no danger to international peace and security and justice; in the absence of risk (Texaco, 1979).

International disputes are usually differences among States over their relationships with each other and with other States (Fatou, 2013). In other words, international disputes are conflicts that occur among two or more countries, between a country and an agency or a public entity, between two entities or public companies, between two societies or cultural groups, between two ethnic groups, between two philosophies or between two classes of countries (Muhammad, 2014). When a dispute grows to a point of a dispute, the international law the dispute settlement comes into play. The most important aspect of this legislation is that all conflicts must be resolved peacefully in such a way that international peace and security as well as justice are not in danger; in the absence of violence.

Among other aspects, the notable features of a ' dispute ' include: there must be the conflict for a dispute to occur. A dispute must contain disputing claims or statements (Baldur, 2012). That is, one party must, in essence, confirm or manifest what it wishes or believes it is entitled to relate to the other, and the other party must express its rejection or its opposing argument. Such a representation must be by declarations, diplomatic documents, and specific actions or on the other hand; and the difference must be precise. That is, it must have a fairly wellexplain subject matter, so that at least nominally, "about" can be said what the conflict is.

It can be remembered, therefore, that disagreement is more than a general attitude of mutual dislike and hatred. Two nations may have a general feeling of antagonism with each other, yet have no particular or concrete disagreement that can be explained as a dispute; on the other hand, two nations must be friendly, yet have a specific disagreement that can be regarded as a general dispute (Kuziemko, 2006).

On the other hand, the 1945 Charter of the United Nations specifies that a dispute must be a legal dispute that results directly from an investment. The idiom ' legal dispute' was used to make it clear that conflicts of interests are within the scope of the centre and pure disputes of interest are not. If a dispute is to be controlled by the centre, one party must be a contracting state and the other party must be a national of another contracting state. Article 25(2) (b) is flexible when it comes to dealing with legal person. It notes that a legal person with the nationality of the contested country Party would be entitled to be a party to proceed under the centre if that country had decided to treat him as the national of another Contracting State due to foreign influence (Dore, 1983).

When a dispute grows to a point of a dispute, the international law the dispute settlement comes into play. The most significant aspect of this legislation is that all disputes must be resolved peacefully in such a way that international peace and security, as well as justice are not in danger; in the absence of violence.

\section{The United Nations Security Council: Its Composition, Powers and Functions}

The UN Security Council is the most significant crisis-management body. The Security Council was given the authority to impose binding obligations on the United Nations member states. It is best known to the public as a principal organ under the UN Charter, responsible for maintaining international peace and security because of challenges including civil wars, natural disasters, arms control and terrorism (R.P. Anand, 1992). 
The UN's other principal organs are the General Assembly: the General Assembly is the UN's deliberative and policy-making body. All Member States are entitled to participate in the General Assembly in which each country has one vote. All the votes are counting the same. Every year in September, the General Assembly begins its session and continues through mid-December. If necessary, special sessions or special emergency sessions are called throughout the year.

Economic and Social Council: 1946 saw the formation of the Economic and Social Council to encourage cooperation on economic and social issues. It also oversees the work of various departments of the United Nations.

International Court of Justice: The United Nations ' main judicial body is the International Court of Justice. It's headquartered in the Hague, Netherlands. It was created under the United Nations Charter chapter. The International Court of Justice statute explain the decision-making power of the court (Lyonette, 1995). The courts also guid on legal issues to the principal UN bodies (A.S. Muller, 1997). The court is made up of 15 judges chosen by the General Assembly and the Security Council (Louis, 1994) for nine years.

Secretariat: The secretariat provides information, studies and all the facilities needed for its meeting by the various UN bodies (Maureen, 2003). The Secretariat is led by the Secretary-General, whose duties include helping to settle international disputes, arranging international conferences, coordinating peacekeeping operations, gathering information on Security Council decisions (International Information, 1997).

Trustee Council: The Trustee Council is responsible for managing and planning for self-government and autonomy eleven trust territories. On 1 November 1994, when the palace, the last remaining UN trust territory, became autonomous, the trustee council's activity was suspended.

To order to implement such critical work, the Security Council, as set out in the constitution, must be able to meet at any time, when the situation demands, approximately two thousand resolutions have been adopted concerning situations around the globe that may be linked to conflict or post-conflict.

In any part of the world, the INSC is responsible for sending a peacekeeping mission to pay a significant role in protecting civilians, making peace agreements, etc. The Security Council has expanded the use of non-military measures like an arms race, travel bans, protecting against natural resource theft, oil disputes, and also taken a leading role in organizing international efforts to combat terrorism.

\subsection{The United Nations Security Council: It's Procedural Rules}

Article 30 of the Charter of the United Nations states that the Security Council adopted its procedure and adopted its provisional rules of procedure in 1946 (S/96). Many times the provisional Rules of Procedure have been amended. The last update was made in 1982 (S/96/Rev7) to introduce Arabic as the sixth official language in compliance with Resolution 35/219 of the General Assembly of 17 December 1980.

Provisional Rules 13-17 control the members of Member States sitting on the committee and the procedure of supplying them with their formal credentials for serving on the committee. Rules 18-20 of the provisional Rules of Procedure control the administrative elements of the Security Council Presidency. This includes the presidency's monthly rotation, details of the president's temporary cession of the chair related to the issues that directly involve his country.

Rules 21-26 of the provisional Rules of Procedure define the Secretary-General's specific functions and powers relevant to the Security Council meetings. Such regulations cover such issues secretariat briefing, reporting, confirmation, statement delivery, and contact with the secretariat and outside and with the newly elected members.

Business conduct is governed by the provisional Rules of Procedure Rules 27-36. This section covers the order of speakers, the ability to create subsidiary organs, voting order, suspension of meetings and amendments and others.

Article 28(1) of the Charter of the United Nations specifies that the Security Council shall act on an ongoing basis and Rules 1-5 of the provisional Rules of Procedure shall include the rules for conducting and convening meetings. To start a council meeting, all the members of the Security Council must be present. If the quorum is not complete, thirty minutes after the Security Council session's scheduled start time, the committee may open the session with the present delegates unless on the other hand directed by the secretariat. When the Security Council formally begins, the quorum is believed.

Before the conference, there must be an agenda. The agenda represents the order in which the Security Council will discuss the issues. This is the original business order to be addressed in the first meeting by the Security Council. The chair can entertain a motion as set out in the section to set the speaking time.

In the event of participation Articles 31 and 32 of the Charter of the United Nations and Rules 37 and 39 of the Security Council's provisional rules of procedure provide for invitations to be extended to non-members of the Security Council to participate without voting, in some situations the Member States are invited under Rule 37, other individuals are invited under Rule 39. It includes united nation members, subordinate bodies, leaders of some organisations including NGOs and others.

In respect to voting matters, Article 27 of the Charter of the United Nations and Rule 40 of the Provisional Rules of Procedure govern the vote in the Security Council. According to Articles 27(2) and 27(3), the decisions of the Security Council on temporary matters shall be taken by an affirmative vote of one vote, while the decisions of the committee on all other issues shall be taken by an affirmative vote of the members, including the votes of 
the permanent members, provided that only a party to a dispute is abstaining from voting in the decisions referred to in Chapter VI and Article 52(3).

\section{A Factual Analysis}

The United Nations also played a significant role in resolving disputes between the contested states over many decades, with the aid of the UNSC (the main body in charge of maintaining peace and security). Whenever a grievance about the contested nations is brought to the UNSC, the Council's first step is to recommend the method of resolving the conflict to the parties concerned, these methods may include arbitration, so that resolution can be reached by peaceful means. The committee itself undertakes investigation and mediation in some cases. Through helping the parties understand the principles of peaceful settlement, the Council has the power to appoint a special representative and recommend that the Secretary-General use his good office to resolve a dispute that poses a threat to peace and security.

The charter also granted the Security Council powers to recommend the condition of agreement to the conflicting parties when they demand it or if the committee thinks that their disagreement is likely to threaten the peace and security of the worlds. If a dispute continues, leading to struggle between/among the states, the committee's primary responsibility is to bring it to an end as soon as possible. The council has ordered ceasefire many times and has managed to prevent unfriendly relationships. When fighting continues, however, it also sends peacekeeping operations from the UN to alleviate instability in troubled areas, creating favourable conditions for preserving peace and security.

The council can impose initiatives, economic sanctions or joint military action in troubled areas to reduce tension. Under the United Nations Charter, the UN Secretary-General has the power to bring any matter to the attention of the Security Council that it thinks may threaten peace and security throughout the world as one of the Secretary's essential or significant rules (Art.52, (2008). General is the use of his ' right office, ' public and private steps taken to rely on his freedom for the sake to prevent international disputes occurring and spreading to other stable territories.

\subsection{Cases Where the UNSC Has Invoked Its Powers To Bring About Settlement of International Disputes:}

It mentioned above, it is evident that the UNSC has been entirely instrumental in settling international disputes between and/or between States that could on the other hand have proved a potential threat to world peace and security. Some of the most noteworthy cases include:

\subsubsection{Iran-Azerbaijan Crisis Case of 1946:}

The first diplomatic confrontation between Iran and the influential USSAR took place after the developing of the UNSC. Throughout World War II, Iran's crisis began in 1942, with Iran signing the agreement authorizing British and Soviet troops to invade Iran to protect their oil-rich nation against potential German attacks. In Steel, too, American troops. The treaty of 1942 agreed that in six months, after the end of the war, all foreign troops would draw (Meister, 1954).

In 1944, Great Britain and the United States began demanding oil concessions from Iran, and the Soviets demanded their concessions (R. Romazani, 1975). By 1945 (Rosevelt, 1947) the oil situation was still unsettled. The war had almost come to an end, however, and the American stance toward the Soviet Union had changed dramatically. The new administration under Herry Truman came to power after Franklin Roosevelt died in April 1945 and decided they could not trust the Soviets. Therefore, a stern stance towards the former warlike has been adopted. Iran has become the test case for the new policy (Lenczowski, 1949).

In Iran, Russia, the Soviets decided to take action in fear of British and American secretly planning to derive them from a proper sphere of influence in Iran. The Soviets, therefore came to the aid of a rebel group in Iran (in Iran's northern regions). The US protested to the UN in early 1946 about the Iran situation and blamed the USSAR for intervening with Iran. A crisis began to develop when a deadline for withdrawing foreign troops from Iran was announced on 2 March 1946, and the Soviets were still in place (Kuniholm, 1980).

A dispute had begun because, despite repeated warnings, the Soviets refused to vacate the occupied Iranian territory. In 1941, Iran was jointly invaded and occupied in the north by the Allied powers of the Soviet Red Army, in the middle by the British and in the south by the Americans as well as by the British to deliver vital supplies to the war efforts of the Soviet Union.

The Allied forces decided, after invading Iran, to withdraw from Iran within six months after the cessation of hostilities. In spite of the arrival deadline, Russia began to invade Iran under Joseph stain in early 1946, and the local pro-Soviet Iranian requested a separate Azerbaijani people's republic (R. Rossow, 1956).

Iran was jointly invaded and occupied in 1941 by the Soviet Red Army's Allied powers in the north and the centre and south by the British. Iran was used as a transportation route by the Americans and the British to supply vital supplies to the war efforts of the Soviet Union.

Apart from the people's republic of Azerbaijan, the Mahabad Republic also came into being in 1945. The coalition of armed forces sponsored by the Kurdish and People's Republic of Azerbaijan resulted in 2,000 deaths (W. Eagleton, 1975). In its wisdom, the Security Council invited the disputing parties to settle a dispute by negotiating amicably. The USSR boycotted the talks, however. This issue remained on the Security Council's agenda calling for the withdrawal of its forces by the USSR (E. Abrahamian, 1982). Finally, Iranian Prime Minister 
Ahmad Oavan's negotiations and US diplomatic pressure on the soviets led to the USSR's withdrawal. This was due to the official U.S. protest, and the UNSC passed Resolution 2, 3, and 5 on January 30, 1946.

\subsubsection{Indonesian Dispute with Holland:}

The Dutch military aggression started on the assault on Yogyakarta, then Indonesia's capital, and the capture of Sukarno, Mohammad Hatta, Sjahrir and some other figures on December 19, 1948. The collapse of the nation's capital led Sjafruddin Prawiranegara to head the Republic of Indonesia's emergency government in Sumatra. The Dutch landed forces at Maguwo Air Base on the first day of the Dutch Military Aggression II and proceeded to the capital of the Republic of Indonesia in Yogyakarta.

The Yogyakarta, Indonesia attack reported 300 soldiers and 53 police death tolls. Nevertheless, it was not determined with certainty the exact number of people who had died. According to the Dutch newspaper De Wappen Broeder published in March 1949, 200 people were killed or wounded during March 1949.

Amid Holland's history of massacre against Indonesia, nations like Australia and India brought this to the International Security Council's attention. The Security Council appointed a Commission to settle the matter with the U.S., Belgium, and Australia representatives. As a result of these states ' efforts in the Hague in July 1949 , the agreement was concluded between the two states and Indonesia became a republic.

\subsubsection{The Berlin Blockade by the Soviet Union:}

A cold war between the two power blocks began after World War II. The U.S. and Communist-led capitalist, dominated by the U.S.S.R. They tried to checkmate each other, leading to a' cold war.' One of the most dramatic stand-offs in the cold war history began when the U.S.S.R. closed the entire road and traffic from and to West Berlin. In 1948, this Berlin Blockade was the Soviet Union's attempt to limit France, Great Britain, and the US's ability to travel to their Berlin industries, which lay in the occupied East Germany of Russia (Nelson, 2978).

At the end of 1947, debate on Germany began on Soviet claims that the Allies breached the Potsdam Treaty, and on March 20, 1948, the Soviets withdrew from the Allied Control committee that controlled Berlin. After ten days, guards on the East German border began to slow down the entry of Western troop trains bound for Berlin on 7 June, and the Western powers announced their intention to proceed with the creation of West Germany, arguing that Berlin could no longer be a single German capital if Germany were to be partitioned. All surface transport between West Germany and Berlin has been prohibited by the soviets.

Therefore, it was obvious that the main cause of the Berlin blockade was the cold war. Stalin, the leader of the soviets, used salami tactics to take over Eastern Europe and Czechoslovakia became a communist. On the other hand, for the sake to control the USSAR, the US had just adopted the Truman Doctrine. Because of the cold war (Durie, 2012), the Berlin Blockade was just another incident between the superpowers.

The United States and the Soviet Union had different goals about what they wanted to do in Germany. That was another explanation for the blockade in Berlin. The USSR had already disagreed on this in Potsdam in July 1945 with Britain and the USA. By stripping East Germany of its wealth and machinery, Stain wanted to destroy Germany. That was what the Soviet Union was trying to accomplish. On the other hand, as an industrial country, Britain and the USA wanted to rebuild Germany and become a wealthy trading partner. Thus, another reason for the Berlin Blockade was the difference in ideas and objectives (Beschloss, 2003). The US and USSR's policy towards Germany was so different that it was clear that sooner or later a US-USSR conflict would break out. The three events that led Stalin to block the borders include: Britain and the United States merged two zones in January 1947 and called the modern region "Bizonia" (two zones) that the Russians opposed because they knew that the Americans and the Britisher were starting to create a new, powerful Germany. The congress voted for Marshall Aid on March 31, 1948. Statin correctly saw this as an attempt to weaken Eastern Europe's Russian influence. Russians immediately began to stop and for search Berlin for all rail and road traffic. The USA and Britain declared on 1 June 1948 that they wanted to create a new country of west Germany and on 23 June 1948 a new currency as implemented in Benzonia and western Berlin citizens in Eastern Europe began to change their money into the new western currency that they felt was more. The Russian halted all traffic on the road and rail into Berlin the next day.

American officials were furious and some in President Harry Truman's government said that the time for negotiation with the USSR was over. Whether the two power blocks (the US and the USSR) will come to blow or fight, the world waited with pressure. The people panicked in West Berlin due to food, water and manual aid shortages (Cherny, 2008). Two days after the Soviets began their blockade, the US response came upon us. Eventually, for nearly a year, the western power resorted to the airlift and brought the much-needed food, medical and other supplies and relief to West Berlin. Just three years after the Second World War, the blockade was the first big cold war confrontation, and Berlin's future was seen as a future conflict zone.

Since Russia blocked Germany's Berlin, France, Canada, and Britain raised the matter to the Security Council. The four powers were discussed by the Security Council (Donovan, 1968). UN members of the four occupying forces agreed to hold an exchange of information on the subject and agreed to lift all restrictions on contact, transport and trade between different zones which they imposed. Therefore, outside the UN, the issue of the Berlin blockade was eventually resolved.

It may be remembered that the venture was a political embarrassment for the Soviets before the resolution of the conflict. Russia appeared like a foreign tyrant trying to put men, women and children to hunger by pressuring 
them to submit. The effective American airlift showed technological superiority over the Soviet Union to the Americans. The Soviets officially ended the blockade after nearly 318 days (eleven months) on May 12, 1949 (Tusa, 1988).

\subsubsection{South and North Korea Case:}

The Korean War began as a civil war between North and South Korea but soon became international when the leadership of the United States and the United Nations joined to support S. Korea. The war resulted in Korea being divided and bringing the cold war to Asia. Rival regimes have been set up. South Korea has become "the Republic of Korea" and North Korea has become "the Democratic People's Republic of Korea" (See, 2010).

Relations between North Korea and South Korea were strained after Korea's division and North Koreans invaded South Korea on June 25, 1950 with little resistance from South Korea. The UN quickly showed its indignation and ordered a withdrawal from South Korea by the worthy Korean troops and also called on its representatives to support South Korea. On June 27, US President Truman authorized the use of American ground, sea and air forces in Korea, a week ago the UN put under our command the powers of fifteen other member nations and General Douglas MacArthur was named Supreme Commander (Cumings, 1990).

Because of the UN invasion, a counter-offensive began on Sep. 15, when UN forces made a courageous landing on the west coast at Inch aeon. Mac Arthur was ordered to follow them into North Korea, leading to Pyongyang's capture. The Chinese Communist, however, joined the North Koreans for a successful counterattack, forcing the U.S. troops to go home, thus recapturing South Korea's capital Seoul (David, 2010).

Perhaps the most serious of the UN's ability to stop the war and sustain world peace was the Korean crisis. UN efforts to achieve a single independent Korean state failed, and in 1948, with a separate government, Korea was split into North Korea and South Korea. This has been brought to the US Security Council's attention. The Security Council agreed and proposed that North Korea should withdraw its troops, but this Security Council resolution was not accepted by North Korea (David, 2008).

The existing evidence confirms and indicates that the blame for the Korean War was the North Korean military with the order of Kim II sung. Yoo Sung Chul who was the director of North Korea's military operation during the Korean War, remembers that to hide that Kim II sung invaded Korea first, the north responded as if South Korea displayed aggressive approach across the 38th parallel and called their invasion as a counterattack order.

The issue was resolved in 1952 and 1953 following talks between the United Nations, China and North Korea. The Korean crisis was the first problem in which UN forces had to march for peace and security to be created. The Korean problem is one of the things that the United Nations has successfully addressed so far.

\subsection{The United Nations Security Council VIS-A-VIS the International Criminal Court:}

The UNSC is the UN's primary organ that carries out the world's primary peacekeeping mission. furthermore to promoting and encouraging respect for human rights and fundamental freedoms for all, as referred to in Article 1, in accordance with the UN Charter of 1945, furthermore directing the UNSC to act in accordance with the aims of the United Nations, Section 3 of the Charter and Article 24, Section 2, the main purpose of the body is to preserve and sustain international peace and security, Take effective and concerted steps or initiatives to avoid and eradicate threats to peace, to deter acts of aggression and to bring about by peaceful means, in accordance with the principles of justice and international law, the resolution of international disputes which may lead to an infringement of peace.

The essential law grants the council the primary responsibility for preserving international peace and security. The essential law also guarantees that UN members agree and accept the Security Council's resolutions and implement them.

Therefore, the UNSC is tasked with both peacefully resolving disputes, if necessary, using the power vested in chapter VI of the constitution and meeting peace threats by proper action under chapter VII. When Chapter VII has been determined by the Security Council. Article 39, that there is a threat to peace, gives the committee the power to decide that measures without the use of armed force should be used to give effect to its decisions and may order the members of the United Nations to enforce those measures. These may involve complete or partial interception of rail, sea, air, mail, radio, telegraphic and other means of communication and economic relationships.

A large number of states argued the court should be exercised universal jurisdiction. This happened during the negotiations leading to the statute of Rome. However, this proposal was defeated because of US opposition. A compromise was reached, allowing the court to expand and exercise jurisdiction in the circumstances such as this. Where the defendant is a member of a state party where the state of the individual has acknowledged the court's jurisdiction; where the alleged crime has been committed on a state party's territory; or where the UNSC referrs the case is by to the court (Elizabeth, 1999).

It is now clear that the commitment of the UNSC to the International Criminal Court has helped propel the International Criminal Court into the international limelight. It has become the main actor where accusations of war crimes, crimes against humanity and acts of genocide of the whole race are at the centre of the jurisdiction of the International Criminal Court. Therefore, in 2005, the committee incorporated the court into Darfur and in 2011, Libya. 
There were nine instances and referrals provided by the Security Council to the International Criminal Court in 2012 itself. In the fall of 201, the committee held a public session on the International Criminal Court, with all the participating states, three permanent committee members who were not parties to the Rome Statute, namely the United States, China and the Russian Federation, expressing a positive view in favor of the court's position (Lucy, 1998). In recent crises, global discourse from Kenya to Mali and Syria to Srilanka focused attention on how the court might be involved in the council's sector.

Adopted in 1998, the International Criminal Court came into force in 2002. It is the first permanent international tribunal to execute international crimes such as race-wide genocide, crimes against humanity and war crimes. International court developing was a landmark in the quest for justice. His research, since then has brought a lot of change in the battle against penalty rights as well as raising new problems in the development of an active international criminal justice system. The court faces many challenges including pursuing challenging ongoing investigations, holding complicated trials, protecting witnesses and promoting their cooperation, creating strategies to execute pending arrest warrants, and many other challenges like this (Fichtelberg, 2009). It is now clear, however, that the problems of the International Criminal Court are significant and tend to be rooted in rhetoric and fact to the UNSC because of its continuing decisions (Nicolaos, 2002). The International Criminal Court was formed related to the United Nations basis on the Rome Statute and has a specific connection with the Security Council, deriving from the authority of the latter under Chapter VII of the UN Charter. The International Criminal Court's relationship with the UNSC is not very clear. It is quite complicated, with the restricted enforcement power, the international criminal court relies on the cooperation and assistance of states that can be strengthened by the Security Council's involvement.

The international criminal court faces challenges brought about by its widely criticized and double standards selectivity and the committees. As the International Criminal Court continues to address the problems, the NNSC is providing financial, economic, diplomatic and logistical assistance to help progress in its position of peace and security. His unusual or odd and wider international area, however, stands in the way of long-term, stable support as a hurdle. This work provides suggestions or recommendations for building a sustainable partnership between the committee and the court that is responsive to the transparency and autonomy mandate of the court and the mandate of the council to preserve international peace and security (Yee, 1999).

\section{Conclusions and Suggestions}

\subsection{Conclusions}

With the passing of the Charter of the United Nations in 1945, the United Nations, an intergovernmental body founded after the Second World War on 24 October 1945 to foster international cooperation that replaced an inadequate League of Nations, had Ensure Global Peacemaker to the United Nations Security Capital and Security In state of the United Nations ' Global Peace Protection National Members.

The UN Security Council's strength relies on both its legal and political environments. The first is derived from the Constitution, and the second is derived from the dominant states ' political interests and the authority the body enjoys in the international system. The Charter grants the committee unprecedented authority in international relations to issue binding state commands and take joint action on behalf of all United Nations Member States in support of international peace and security. This legal authority only comes into effect when there is enough consensus among the permanent members of the committee to allow it to happen, and only when the broader audience of Council resolutions recognizes the action as valid.

The secret council has authorized action and punishment, and the member has a role to a vital from the Korean War to most of the International committee until the issue reacts i.e. War in the Gulf.

For various actions, the Security Council empowered and, if necessary, also imposed a sanction and acute disobey of international peace and security. The Security Council plays an important role in worldwide peace and order.

The NATO force, consisting of five permanent members, has reserved five Security Council seats and the remaining ten sets are non-permanent members for the countries serving two years. And serving for two years. For a security council, the participant members can have participate. The members can vote for their benefit that they can enjoy their diplomatic role in the political advantage of the financial during their paid power. The Security Council is supposed to study problems related to economic corruption, which is frequently debated as to whether council members related to payment of foreign aid.

Article 24 of the Charter of United Nations, the principal object of which is to constitute a Security Council, is to twin the peace and order of a Security Council on behalf of a member and a representative of the State. Article 24 of the Charter of United Nations, the principal object of which is to constitute a Security Council, is to twin the peace and order of a Security Council on behalf of a member and a representative of the State.

Study shows that the State Security Council provides the non-democratic member with the opportunity to explain their short idiom in the Global salience that the rough trade and prow ding security \& foreign exchange aid policy can be done. Help is Nat to Nat in the form of out-crystals, people who do products and people who are in need. Aid does not trade for development, as few nations collect, but benefits in condition of economic and patient quality and international peace and security. We are focused on peace and security as voluble compromises. The result indicates that support has no adverse impact on growth but that effect by design rather than by accident. 
Help means, Democratic government having a political concession from less well to represent non-democratic regimes by UNSC election is a step towards enhancing foreign aid and global security of immediately affecting poor worlds for the better step towards developing condition.

Concerning to the mechanisms used by the UNSC to settle international disputes, international disputes between nations are resolved and not resolved by a wide field of methods that are possibly the least prevalent in adjudication. Political rewards are the key driver, and it is often impossible to reconcile the range of political ideologies because nations are not prepared to compromise. There are peaceful ways of resolving property disputes: informal agreements, good offices, mediation, enquiry and conciliation, consultation, arbitration, and legal settlement. Conciliation is a dispute settlement tool may play a valuable role in transnational economic dispute settlement as an early, informal procedure that, if successful, overlooks the need for adjudicative processes to be resorted to. This allows an impartial third party to settle a dispute while preserving procedural flexibility and the contestants ' overall right to choose whether or not to follow the advice of the conciliator.

Mediation is included throughout the transnational process in its classic and hybrid forms the dispute resolution systems. Mediation, however, is not commonly used in practice, especially when compared to arbitration. The only exception to this rule, whether multilateral or bilateral, is the use of conciliation strategies in international trade agreements. As an integral element the dispute resolution, the GATT and most free trade agreements include conciliation aspects in one form or another. Since these systems are the mechanisms required to resolve disputes over the treaties, the conciliatory techniques are used regularly.

By comparison, while conciliation is sometimes used in other contractual agreements and can be used to resolve private disputes, it is rarely used in either of these fields when there are international economic or business disputes. This may be due in part to the youth of many conciliation option-including provisions. Nonetheless, the increasingly increased use of arbitration in settlements where both options are available means that if the conflict cannot be resolved by mediation, most disputants, be they states or private entities, follow the adjudicative path.

This action is likely to be established by binding, adversarial approaches in the Western tradition of conflict determination. Eastern players ' more significant presence in the contemporary transnational economic system has altered this focus just marginally, typically in the Pacific Rim countries. Whether this phenomenon will continue or whether the new players will gradually adhere to the pattern of adjudication instead is unclear. However, conciliation serves a valuable role within well- explained limits and must be taken seriously when writing or accessing dispute resolution structures. Conciliation needs to be introduced as the first move in a complex system more often than it is at present. It can resolve an international business dispute efficiently, removing the need for adjudicative arbitration processes, but not the accessibility.

Protecting global peace and its stability is the main purpose for the advancement of human rights and the protection of human rights, the primary goal of the UN to strive for better security and to preserve the same for global peace once peace and justice are obtained without violence, i.e. by means of good office negotiation, etc. And using by the way peaceful settlement to achieve a feeling restored world peace and security is the desired achievement there are different methods of settlement adjudication on the system for settling disputes reduces political antagonism and transfer between the parties the essential of this method is the lack of political dominance covering the matter.

The study showed that / Determined / Highlighted government opted to go to agreement that had a political effect rather than adjudication. Neither government likes to lose its political control over the matter that is enthusiastic about the future cases the political influence is played by countries that are a powerful nation and take advantage of its most tested international organization shop as disloyalty to global dictation change.

There is some room for the adjudication to consider international court reliance on the procedure when it relates to the fact that the court continues to pass question without appeal to the parties to the issue. In some situations, the Court distinguishes a legal area of justice in the matter - case law, Slovakia and Hungary can find that the status in which the court ruled the case must be decided by means of vegetation in good faith with the majority of vibes and also to ensure that the purposes of the treaty negotiated between the countries on 16 Sept. 1993 were accomplished as agreed.

\subsection{Suggestions}

The UN Charter maintained the responsibility of the Security Council to preserve and secure international peace and security. The flue permanent members plays a crucial role, and the Flaws strengthened the changes. These five permanent members, i.e. veto power, gain sufficient power and may influence the Security Council's decision to use the Security Council's decision for the reason they think they have it in their hands for their agenda.

To improvement the Charter of the United Nations requires the veto member's support and consent to agree on reform in the United Nations. Member of the U.N. reform. Even as the UN member agrees, the veto powers for the improvement should be accepted and affirmed.

\section{References}

A. Garner. 1999. Black's Law Dictionary.

1. A.S. Muller, D. Raic and J.M. Thuranszky. (1997). The International Court of Justice: Its Future Role after Fifty Years, p. 51. See also, Gilbert Guillaume, The Future of International Judicial Institutions, International and Comparative Law Quarterly (I.C.L.Q), vol. 4 (October 1955), pp. 848-49. 
2. Abrahamian, Iran between two Revolutions, Princeton, 1982, pp. 169-246, 281-312, 326-415.

3. Adam Roberts. (2000). Keeping Faith with the UN, (London, Dortrecht).

4. Arnold Chopra. (2001). New Tasks for the United Nations 12, (London, Routledge); John Mara,

5. Art.24. (1945). The Foundational Treaty of the United Nations Charter.

6. Art.52. (2008). The Charter of United Nations. In its Presidential Statement of 23 September (S/PRST/2008/36), the Security Council underlined 'the importance of mediation as a means of pacific settlement the disputes, and encourages the further use of this mechanism in the settlement the disputes'.

7. Baldur Thorhallsson. (2012). Small States in the UN Security Council: Means of Influence? The Hague Journal of Diplomacy 7, 135, 152-160.

8. Beschloss, Michael R. (2003). The Conquerors: Roosevelt, Truman and the Destruction of Hitler's Germany, 1941-1945.

9. Cherny, Andrei. (2008). The Candy Bombers: The Untold Story of the Berlin Airlift and America's Finest Hour, New York: G.P. Putnam's Sons.

10. Christian Brocker. (2000). UN Security Council: Snapping the snare, 17, (New York, Greenwood press.

11. Cumings, Bruce. (1990). The Origins of the Korean war (Princeton University Press).

12. David Halberstam. (2010). The Coldest Winter: America and the Korean War, (Hyperion, 2008); CNN Wire Staff. (23 November 2010). Korean Tension: A Look at the Conflict - CNN.com.

13. Donovan, Frank. (1968). Bridge in the Sky, (New York: David McKay Inc).

14. Dore. (1983). Peaceful Settlement of International Trade Disputes: Analysis of the Scope of Application of the Unilateral Conciliation Rules, 21 COLUM. J. TRANSNAT'L L. 339 (1983).

15. Durie, W. (2012). The British Garrison Berlin 1945-1994 "Nowhere to go", (Berlin: Vergangenheits/Berlin).

16. Elizabeth Wilmshurst, 1999. 'Jurisdiction of the Court', p. 136. In Roy S Lee (ed.), The International Criminal Court: The Making of the Rome Statute. The Hague: Kluwer Law International.

17. Fatou Bensouda. (2013). International Justice and Diplomacy, International Herald Tribune, March 19.

18. Fichtelberg, Aaron. (2009). "Fair Trials and International Courts: A Critical Evaluation of the Nuremberg Legacy." Criminal Justice Ethics 28.1: 5-24. ProQuest Criminal Justice. Web. 16 Oct. 2013.

19. G. Lenczowski. (1949). Russia and the West in Iran 1918-1948, Ithaca.

20. International Information: Documents, Publications and Electronic Information of International Government Organizations, 2d ed. (Peter I. Hajnal, 1997).

21. Interpretation of the Peace Treaties with Bulgaria, Hungary and Romania, Advisory Opinion of 30 March 1950 (first phase), 1950 ICJ Rep. 65, at 74.

22. Kuniholm, (1980). The Origins of the Cold War in the Near East: Great Power Conflict and Diplomacy in Iran, Turkey, and Greece, Princeton, pp. 140-216, 270-350, 376-99, 425-31.

23. Kuziemko, Ilyana and Eric Werker. 92006). How Much Is a Seat on the Security Council Worth? Foreign Aid and Bribery at the United Nations. Journal of Political Economy 114(5): 905-930

24. Lau Breckon. (2005.). The New Role of the United Nations, Voting in the Security Council, Vol4, p.5, London, Macmillan, Vol.7, Singapore, Dartmouth.

25. Louis B. Sohn. (1944). The Jurisdiction of the ICJ, AJIL, vol. 38, p. 694. No two judges can be nationals of the same State, and the principal legal systems of the world are represented on the court.

26. Lucy S. Sunga. (1998). The Crimes within the Jurisdiction of the International Criminal Court (Part II, Articles 5-10)", European Journal of Crime, Criminal Law and Criminal Justice vol. 6, no. 4, pp. 377399.

27. Lyonette Louis-Jacques \& Jeanne S. Korman. (1995). Introduction to International Organizations.

28. Magazine. (2005). The Evolving United Nations: Principles and Realities, Vol. 12, p.4, Nairobi, Lancaster House.

29. Maureen Ratynski Andersen. (2003). Where to Begin ... When You Don't Know How to Start: Tips for Researching U.N. Legal Materials, 31 Int'l J. Legal Info. 264.

30. Meister. (1954). Soviet Policy in Iran, 1917-1950: A Case Study in Techniques, Ph. D. dissertation, Fletcher School of Law and Diplomacy, Tufts University.

32. Nelson, Daniel J. (1978). Wartime Origins of the Berlin Dilemma (Alabama: University of Alabama Press).

33. Nicolaos Strapatsas. 2002. "Universal Jurisdiction and the International Criminal Court", Manitoba Law Journal, vol. 29, p. 2.

34. R.P. Anand. (1992). The World Court on Trial||, in R.S. Pathak and R.P. Dhokalia, International Law in Transition: Essays in Memory of Judge Nagendra Singh 45 (New Delhi).

35. R. Romazani. (1975). Iran's Foreign Policy, 1941-1973: A Study of Foreign Policy in Modernizing Nations, Charlottesville 91-178.

36. R. Rossow. (1956). "The Battle of Azerbaijan, 1946," The Middle East Journal 10, Winter, pp. 17-32.

37. Rosevelt, Jr. (1947). The Kurdish Republic of Mahabad. The Middle East Journal, pp. 256-57.

38. Sahara Okhovat. (2011). The United Nations Security Council: Its Veto Power and Its Reform 7 , CPACS Working Paper No. 5/1, December. 
39. See, R. E. (2010). Appleman, South to the Nakong, North to the Yalu (1961); D. Rees, Korea (1964); B. I. Kaufman, The Korean War (1986); I. F. Stone, The Hidden History of the Korean War (1988); C. Blair, The Forgotten War (1989); S. Weintraub, MacArthur's War (2000); D. Halberstam, The Coldest Winter (2007); B. Cumings, The Origins of the Korean War (2 vol., 2004) and The Korean War: A History (2010).

40. Shabtai Rosenne. (2006). The Law and Practice of the International Court of Justice 1920-2005 4th edn, (Martinus Nijhoft, Leiden).

41. Sydney Bailey. (1998). The United Nations in the Twenty-First Century 19, (New York, Prentice Hall, 2001); Sydney Bailey, The Procedures of the United Nations Security Council, 92, Oxford, Clarendon).

42. Texaco Overseas Petroleum Company and California Asiatic Oil Company v. Libyan Arab Republic. (1979). Preliminary Award of 27 November 1975, 53 ILR 389, at 416.

43. Tusa, Ann and John. (1988). The Berlin Airlift (New York: Atheneum).

44. Under Arts. 2 (4), 42 and 51 . (1945). Of the United Nations Charter, armed conflict or the use of military force in international relation is generally prohibited by the UN Charter unless such a force is used in self-defence or authorized by the UN Security Council.

45. W. Eagleton, The Kurdish Republic of 1946, London, 1963. E. Hooglund, Land and Revolution in Iran, 1960-1980, Austin, 1982; Idem, "The Autonomous Republic of Azerbaijan and the Kurdish People's Republic: Their Rise and Fall," in The Anatomy of Communist Takeovers, T. Hammond, ed., New Haven, 1975, pp. 448-74.

46. Yee, Lionel. (1999). "The International Criminal Court and the Security Council: Articles 13(b) and 16". In Roy S. Lee (ed.). The International Criminal Court: The Making of the Rome Statute. The Hague: Kluwer Law International, p. 150 (stating delegates opposed the original ILC draft for reasons of political interference in the Court by the Security Council). 